\title{
Growth performance and haematological characteristics of starter broilers fed diets supplemented with tumeric (Curcuma longa) meal \\ ${ }^{1}$ Olabode, A. D., ${ }^{1}$ Adetutu, I. S., ${ }^{2}$ Agu, C. I., ${ }^{3}$ Ugwuowo, L. C., ${ }^{1}$ Ojuoloruntaye, T. J. and \\ ${ }^{4}$ Okelola, O. E. \\ ${ }^{I}$ Federal College of Agriculture, Ishiagu, Ebonyi state. \\ ${ }^{2}$ Enugu state polytechnic, Iwollo, Ezeagu, Enugu state. \\ ${ }^{3}$ Nnamdi Azikiwe University Awka, Anambra state. \\ ${ }^{4}$ Federal College of Fisheries and Marine Technology, \\ Victoria Island, Lagos state.
}

Abstract Corresponding author: adeoladavid2005@yahoo.com; 08063379970

Turmeric (Curcuma longa) is an extensively used spice, food preservative and coloring material that has biological actions and medicinal applications. Tumeric, when used as an additive could enhance the performance of broiler chickens in Nigeria. The aim of the present study was to assess the growth performance and haematological characteristics of starter broiler chicken fed diets supplemented with processed turmeric) meal (TM). Ninetysix, two weeks old unsexed "Agri-tech" broiler birds were randomly distributed in a completely randomized design (CRD) into four treatments, comprising of twenty four birds each, with three replicates per treatment (having 8 birds per replicate). The processed turmeric was included at the rate of $0 \%, 0.5 \%, 1.0 \%$ and $1.5 \%$ respectively. Feed and water were given without restriction. Supplementation of processed turmeric meal in the diet of starter broilers significantly $(p<0.05)$ influenced the final body weight, average daily feed intake, average daily weight gain and feed conversion ratio. The treatment groups containing processed turmeric meal had poor performance in all parameters studied when compared to that of the control. Mean values of all haematological parameters evaluated namely; packed cell volume (PCV), haemoglobin ( $H b)$, red blood cell (RBC) and white blood cell $(W B C)$ differed significantly $(p<0.05)$ between the control and the turmeric treated groups, however all the values obtained were within the recommended standard range of values for broiler. It was concluded that processed turmeric meal can be added to the diets of starter broilers up to the level of $1.5 \%$ and also can be safely used as a phyto-additive in starter broiler chickens, preferably in theirfeed.

Keywords: Growth performance, supplemented, starter broiler, turmeric meal, haematology

\section{Introduction}

The low level of animal protein consumption by Africans in general and Nigerians specifically is a reflection of the state of deterioration of the Nigerian livestock sector, especially poultry which has continued to show a discouraging slow rate of growth (Martins, 2001). Thus a realistic step towards enhancing animal protein supply and intake in Nigeria is the development and expansion of the poultry industry (Onyimonyi et al., 2009; Olabode et al., 2013). Despite the privileged role accorded the poultry industry, its future development depends to a large extent on the supply of appropriate, safe and cost effective feeds. The interest in feed additives grew over the last decade as the usage continues to increase across the country. These feed additives have received a high attention as feed supplements for various purposes in poultry production during the recent years (Zhang et al., 2009). Some of the beneficial effects of bioactive 


\section{Broilers fed diets supplemented with tumeric (Curcuma longa) meal}

plant substance in animal nutrition may include the stimulation of appetite and feed intake.

Turmeric (Curcuma longa) is an extensively used spice, food preservative and coloring material that has biological actions and medicinal applications (Akpbarian et al., 2012). The significant biological properties of turmeric make it a potential substitute for use as a feed additive in livestock diets. The active and main ingredient found in turmeric plants is the curcumin, which has been found to have antioxidant and antibacterial activities (Kerami et al., 2011). Over the years turmeric has proved to have a protective effect as a feed additive on aflatoxin-induced mutagenicity and hepatocarcingenicity in livestock production. The aim of the present study is to assess the growth performance and hematological assay of broiler chickens at starter phase given diets supplemented with processed turmeric (Curcuma longa).

\section{Materials and methods}

The experiment was carried out at the poultry unit of the Federal College of Agriculture, Ishiagu, Ebonyi state. The experiment lasted for a period of five weeks. The test ingredient, which is turmeric was sourced at the Research Institute, Umudike and also locally at the Ogbete main market, Enugu state. The fresh turmeric was peeled, cleaned and washed, and later sundried before been crushed into powder form at the college feed mill.

A total of 96 day old Agri-tech broiler chicks were used for the experiment. The birds were randomly distributed into four treatments namely, T1, T2, T3 and T4. Each treatment was replicated three times, with eight birds per replicate and twenty-four birds per treatment. The birds were raised on a deep litter system with wood shavings serving as a source of litter. All chicks were raised in a well ventilated and sanitized deep litter broiler poultry house using wood shavings as litter materials. Similar routine management practices were maintained for all the treatment groups. The birds were vaccinated on schedule against Newcastle, gumboro and fowl pox disease.

Determination of daily feed intake was done by obtaining the difference between the quantity of feed offered and the left over the following morning. All chicks were weighed at the beginning and at the end of the study, the weight was taken weekly. The body weight gain was calculated by subtracting the initial body weight from the final body weight. The body weight change (daily body weight gain) was obtained by dividing the body weight gain by the number of days the experiment lasted. Data generated was used to calculate the feed conversion ratio. The quantity of feed consumed compared with the unit gain as a measure of the efficiency of the feed given. This was expressed as the ratio of daily feed intake to daily weight gain. At the end of the feeding trial, blood samples $\left(2 \mathrm{mLs}\right.$ bird $\left.^{-1}\right)$ were randomly collected from one bird per replicate (three birds per treatment) from the wing vein with a sterile needle into welllabeled sterilized bottles containing EDTA as an anticoagulant. These were used for the hematological analysis to estimate the Packed Cell Volume (PCV). Hemoglobin count $(\mathrm{Hb})$, Red Blood Cell (RBC) and White Blood Cell (WBC). Data obtained were subjected to analysis of variance (ANOVA) according to A.O.A.C (2005).

\section{Results and discussion}

The growth performance traits of birds given the experimental diets are presented in Table 3. Supplementation of processed turmeric meal in the diets of starter broiler birds significantly $(p<0.05)$ influenced the final live weight, daily feed intake, daily body weight gain and feed conversion ratio. The result for the final body weight showed 
Olabode, Adetutu, Agu, Ugwuowo, Ojuoloruntaye and Okelola

Table 1: Composition of starter broiler diet

\begin{tabular}{lcccc} 
& \multicolumn{3}{c}{ Treatments } \\
\cline { 2 - 5 } Parameters & $\mathrm{T} 1(0 \% \mathrm{tm})$ & $\mathrm{T} 2(0.5 \% \mathrm{tm})$ & $\mathrm{T} 3(1.0 \% \mathrm{tm})$ & $\mathrm{T} 4(1.5 \% \mathrm{tm})$ \\
\hline Maize & 52.25 & 51.75 & 51.75 & 51.75 \\
Wheat offal & 9.50 & 9.50 & 9.00 & 9.00 \\
Groundnut cake & 22.15 & 22.15 & 22.15 & 21.65 \\
Total & 100 & 100 & 100 & 100 \\
\hline Other feed ingredient had the same value across the treatment group. Soybean meal & $-5.00 ;$ Fishmeal-3.00; Bloodmeal-3.00; Bonemeal -2.50; \\
Limestone-1.50; Salt-0.25; Starter premix-0.30; Lysine-0.25; Methionine-0.30. & &
\end{tabular}

Table 2: Proximate composition of turmeric meal (on dry matter basis)

\begin{tabular}{lc}
\hline Component & \% Composition \\
\hline Crude protein & 10.32 \\
Crude fiber & 4.78 \\
Ether extract & 7.40 \\
Ash content & 3.98 \\
Nitrogen free extract & 3.52 \\
\hline
\end{tabular}

that birds in treatment 1 (control) had the highest value of $1385 \mathrm{~g}$ which was similar $(p>0.05)$ to those of birds in treatment 2 $(1357 \mathrm{~g})$, but different $(\mathrm{p}<0.05)$ from those in treatment 3 (1244 g) and 4 (1159 g) respectively. The significant decrease in value for final body weight across the treatment group may be due to the inability of the birds' enzymatic system to stimulate protein synthesis and also optimized the antioxidant activities of turmeric. This present research work is in contrast with the work of Samarasinghe et al. (2003) who found out that inclusion of turmeric meal in the diet increased their body weight. Average daily feed intake showed significant $(\mathrm{p}<0.05)$ effect among treatment group. Values for birds in treatment $1(98.37 \mathrm{~g})$ was similar $(\mathrm{p}>0.05)$ to those on treatment $2(97.20 \mathrm{~g})$, but was significantly $(\mathrm{p}<0.05)$ different from those obtained for birds on treatment 3 (90.18 g) and $4(88.66 \mathrm{~g})$. The result obtained in this study was in agreement with the work carried out by Rajput et al. (2013) that reported a significant difference in feed consumption when dried processed turmeric meal was offered to broiler birds, but disagreed with the observation of Nouzarian et al. (2011) who observed no significant $(\mathrm{p}>0.05)$ differences when turmeric meal was fed to starter broiler chicks. Thus, the low level of feed intake observed in treatments containing turmeric meal could be due to the inability of the birds' gut to maximize the turmeric meal due to its colour and taste imparted on the diets.

Table 3. Growth performance characteristics of starter broilers fed diet supplemented with processed turmeric meal

\begin{tabular}{lccccc}
\hline & \multicolumn{5}{c}{ Treatments } \\
\cline { 2 - 6 } Parameters & T1 & T2 & T3 & T4 & SEM \\
\hline Initial body Weight $(\mathrm{g})$ & 259 & 253 & 259 & 257 & - \\
Final body weight $(\mathrm{g})$ & $1385^{\mathrm{a}}$ & $1357^{\mathrm{a}}$ & $1244^{\mathrm{b}}$ & $1159^{\mathrm{c}}$ & 35.33 \\
Av. Daily weight gain $(\mathrm{g})$ & $53.62^{\mathrm{a}}$ & $52.57^{\mathrm{a}}$ & $46.91^{\mathrm{b}}$ & $42.95^{\mathrm{c}}$ & 1.70 \\
Av. Daily feed intake $(\mathrm{g})$ & $98.37^{\mathrm{a}}$ & $97.10^{\mathrm{a}}$ & $90.18^{\mathrm{b}}$ & $88.66^{\mathrm{c}}$ & 1.39 \\
Feed conversion ratio & $1.84^{\mathrm{c}}$ & $1.85^{\mathrm{c}}$ & $1.92^{\mathrm{b}}$ & $2.06^{\mathrm{a}}$ & 0.05 \\
\hline
\end{tabular}

${ }^{a b c}$ Means on the same row with different superscripts are significantly $(\mathrm{p}<0.05)$ different.

$\mathrm{SEM}=$ Standard error of mean . 


\section{Broilers fed diets supplemented with tumeric (Curcuma longa) meal}

The result of the haematological indices of starter broilers fed diets supplemented with processed turmeric meal is presented in Table 4. Haematological parameters are good indicators of the physiological status of the animal (Esonu et al., 2006). The blood parameters for hematology were significantly $(\mathrm{p}<0.05)$ affected by the Curcuma longa across the treatment group, even though they did not follow a particular pattern. All values obtained for packed cell volume (PCV), hemoglobin $(\mathrm{Hb})$, red blood cell (RBC) and white blood cell
(WBC) studied falls within the normal ranges for broiler as reported by The Merck Veterinary Manual (2015). The results obtained in the present study contradicts the findings of Abou-Elkhair et al. (2014) who reported that inclusion of turmeric meal in the diet of starter broilers had no effect on $\mathrm{PCV}, \mathrm{Hb}, \mathrm{RBC}$ and $\mathrm{WBC}$ respectively. The improvement in the haematological constituents observed in the present study is an indication that the inclusion of turmeric meal did not show any pathological effect on the bird thus did not cause or create any haematological disorder.

Table 4. Haematological characteristics of starter broilers fed diet supplemented with processed turmeric meal

\begin{tabular}{llllll}
\hline & \multicolumn{5}{c}{ Treatments } \\
\cline { 2 - 5 } Parameters & T1 & T2 & T3 & T4 & SEM \\
\hline & & & & \\
Packed cell volume $(\%)$ & $22^{\mathrm{a}}$ & $22^{\mathrm{a}}$ & $15^{\mathrm{b}}$ & $21^{\mathrm{a}}$ & 0.87 \\
Haemoglobin $(\mathrm{g} / \mathrm{d})$ & $7.3^{\mathrm{a}}$ & $7.4^{\mathrm{a}}$ & $5.0^{\mathrm{b}}$ & $7.0^{\mathrm{a}}$ & 0.30 \\
Red blood cell $\left(\mathrm{x} 10^{12 / 1}\right)$ & $2.3^{\mathrm{a}}$ & $2.6^{\mathrm{a}}$ & $1.6^{\mathrm{b}}$ & $2.6^{\mathrm{a}}$ & 0.13 \\
White blood cell $\left(\mathrm{x} 10^{9 / 1}\right)$ & $5.4^{\mathrm{c}}$ & $6.2^{\mathrm{b}}$ & $4.5^{\mathrm{d}}$ & $7.5^{\mathrm{a}}$ & 0.34 \\
abcd Means on the same row with different superscripts are significantly $(\mathrm{p}<0.05)$ different. \\
SEM = Standard error of mean.
\end{tabular}

$\mathrm{SEM}=$ Standard error of mean

\section{Conclusion}

The study indicated that the use of turmeric meal in the diets of broiler chickens does not have any adverse effect on them. Thus, the addition of turmeric meal up to $1.5 \%$ can be tolerated by the broiler birds at their starter stage without any negative effect. In conclusion, turmeric meal could be safely used as a phyto-additive for broiler chickens.

\section{References}

Abou-Elkhair, R., Ahmed, H. A. and Selim, S. 2014. Effect of black pepper (Piper nigrum), turmeric powder (Curcuma longa) and coriander seeds (Coriandrum sativum) and their combinations as feed additives on growth performance, carcass traits, some blood parameters and humoral immune response of broiler chickens. AsianAustalas. J. Anim. Sci., 27(6):847-854.

Akbarian, A., Abolghasem, G., Ahmadi, S. and Hossein, M. 2012. Effect of ginger root (Zingiber officinale) on the egg yolk cholesterol, antioxidant status and performance of laying hens. Journal of Applied Animal Science,39: 19-21.

AOAC. 2005. Association of Official Analytical Chemists. Official methods of Analysis. $18^{\text {th }}$ edition. AOAC Inc. Arlingon, Virginia, USA.

Esonu, B. O., Opara, M. N., Okoli, I. C., Obikaonu, H. O., Udedibie, C. and Iheshiulor, O. M. 2006. Physiological response of laying birds to neemleaf meal based diets; body weight, organ 


\section{Olabode, Adetutu, Agu, Ugwuowo, Ojuoloruntaye and Okelola}

characteristics and hematology. Online Journal of Health and Allied Science, 5: 26-30.

Kerami, M., Alimon, A. R., Sazili, A. Q., Goh, Y. M. and Ivan, M. 2011. Effect of dietary antioxidants on the quality, fatty acid profile and lipid oxidation of longissimus muscle in Kacang goat with aging time. Meat Sci.,88: 102108.

Kumara, P. M. K., Gupta, R., Ranjan, K. K., Singh, R. and Yadava, R. 2007 Curcuma longa as feed additive in broiler birds and its pathophysiological effects. Indian Poultry Science, 40: 137141.

Martins, A. M. 2001. The future of the world food system. Outlook on Agriculture, 30: 11-19.

Nouzarian, R., Tabeidian, S. A., Toghyani, M., Ghalamkari, G. and Toghyani, M. 2011. Effect of turmeric powder on performance, carcass traits, humoral immune responses and serum metabolites in broiler chickens. J. Anim. and Feed Sci., 20:389-400.

Olabode, A. D., Onyimonyi, A. E., Ezekwe, A. G. and Okelola, O. E. 2013 . Performance characteristics and economic evaluation of laying birds fed graded levels of neem leaf meal. Inter. J. Agric. BioSci, 2(5):213216

Olabode, A. D., Ojuoloruntaye, T. J., Agu, C. I. and Okelola, O. E. 2018. Performance and haematological characteristics of starter broilers fed diet supplemented with turmeric (Curcuma longa) meal. Proceeding of the Nigerian Society for Animal Production,
43: 180-182.

Onyimonyi, A. E., Olabode, A. D and Okeke, G. C 2009. Performance and economic characteristics of broilers fed varying levels of neem leaf meal. International Journal of Poultry Science, 8(3): 256-259.

Raghdad, A. and Al-Jaleel, A. 2012. Use of turmeric (Curcuma longa) on the performance and some physiological traits of broiler birds. The Iraqi Journal of Veterinary Medicine, 36(1):5157.

Rajput, N., Muhammed, N., Yaan, R., Zhang, X. and Wang, T. 2013. Effect of d i e t a r y supplementation of curcumin on growth performance, intestinal morphology and nutrients utilizationof broiler chicks. $J$. Poult. Sci., 50: 44-52.

Samarasinghe, K., WenkSilvak, K. and Gunasekera, J. 2003. Turmeric (Curcuma longa) root powder and mannan-oligossacharides as alternatives to antibiotics in broiler chicken diets. AsianAustralas. J. Anim. Sci., 16(10): 1495-1500.

The Merck Veterinary Manual 2015. Recommended nutrient level for pullet chicken. A subsidiaryof Merck and Co. Inc., Kenilworth, N.J., U.S.A

Zhang, G. F., Yang, Z. B., Wang, Y., Yang, W. R., Jiang, S. Z. and Gai, G. S. 2009. Effects of ginger root (Zingiber officinale) processed to different particle sizes on growth performance, antioxidant status and serum metabolites of broiler chickens. Poultry Science, 88:2159-2166.

Received: $26^{\text {th }}$ July, 2018 Accepted: $21^{\text {st }}$ December, 2018 